\title{
ПОНЯТТЯ ТА ЗМІСТ ІНФОРМАТИЗАЦІЇ ОСВІТИ В КОНТЕКСТІ ГЛОБАЛЬНИХ ВИКЛИКІВ СУЧАСНОСТІ
}

\author{
КАПУШ Унна Ігорівна - здобувач кафедри адміністративного права і процесу, \\ фінансового права, інформаційного права Приватного вищого навчального \\ закладу «Львівський університет бізнесу та права»
}

DOI:10.32782/NP.2019.4.29

УДК 342.23:012

В статье исследовань вопрось инборматизачии образования, которая находит свое выражение в поиске дальнейших путей инборматизации образовательной сферь, определение роли и места этого процесса в реализации современных концепций модернизачии отечественной системы образования и вхождения ее в мировое образовательное пространство в условиях евроинтеграции и становления информационного общества. Раскрытто инборматизацию образования как многоаспектный процесс, поскольку комплексное решение проблемь должно предусматривать использование информачионных технологий во всех сферах образовательной жизни - учебном процессе, методической работе преподавателей, решении административных и управленческих задач и тому подобное.

Ключевъе слова: инборматизачия образования, ИКТ, образовательная среда, глобализачия, трансбормачия общества, конкурентоспособность, рълнок труда.

\section{Постановка проблеми}

Аюдство вступило в ХXI століття - століття інформатизації і глобальних змін в житті світового співтовариства. Науковці вважають, що сьогодні створено два типи мереж. Інтернет-мережі комп'ютерів, що забезпечуються набором інформаційних технологій, i «багаторівневі просуваючі мережі, характерні набором гуманітарних технологій. Створено практично два типи мереж, одним з яких у мережі пов'язані комп'ютери, а в другому - безпосередньо люди. Багато- рівневий маркетинг надзвичайно схожий на Інтернет, але тільки побудований він на живому матеріалі. Це означає, що на перший план в найближчий час вийде не здатність засвоювати простіший набір операцій (тобто не хороша освіченість), а вміння навчатися упродовж усього життя, адже тільки люди, котрі здатні перевчатися 7-8 разів упродовж свого життя, будуть конкурентоздатними на ринку праці. Інакше кажучи, в майбутньому світі буде затребуваною тільки та людина у якої виявиться специфічна якість: здатність до того, щоб перевчатися. Можна сказати й так, що виникатиме здатність до зміни, здатність до самозміни» [1].

Отже, нові цілі модернізації освітньої галузі, через концепт Нової української школи, спрямовані на розвиток національної системи освіти, що має відповідати викликам часу та потребам особи, яка здатна реалізувати себе в інформаційному суспільстві, що постійно змінюється. Сучасна філософія освіти потребує принципово нових наукових досліджень, обгрунтованих і послідовно запроваджених передових науково-педагогічних технологій, раціональних та ефективних підходів до організації наукової та інноваційної діяльності у сфері освіти, у тому числі через застосування інформаційно-комунікаційних технологій (ІКТ) [2, с. 3].

\section{Стан дослідження проблеми}

Деякі аспекти питання інформатизації окремих сфер були предметом дослідження багатьох вчених, 3-поміж яких варто звер- 
нути увагу на наукові розвідки I. Арістової, О. Баранова, К. Бєлякова, Н. Бортник, В. Гавловського, М. Гуцалюка, І. Жиляєва, С. Єсімова, Р. Калюжного, Н. Мороз, А. Новицького, Н. Новицької, В. Цимбалюка, В. Хахановського, I. Хомишин, М. Швеця та iн.

Метою статті є дослідження окремих аспектів інформатизації, зумовлюють потребу подальшої інформатизації освіти в контексті глобальних викликів сучасності.

\section{Виклад основного матеріалу}

Тенденція підвищення інтересу до наукових досліджень усіх складників освіти як соціального інституту і соціального феномена, що спостерігається в Україні сьогодні, пов'язана насамперед з усвідомленням ролі й місця освіти у формуванні інтелектуального та культурного потенціалу нації як джерела соціального досвіду. В умовах зростання значення інформації і комунікації в людському житті та формування інформаційного типу суспільного розвитку мета формування єдиного освітнього простору в рамках усієї світової спільноти набуває першочергового значення. Виходячи з цього, актуальність досліджень сучасних змін освітньої системи обумовлена, з одного боку, не тільки необхідністю вивчення нового стану освіти, але і не менш істотною потребою визначення перспектив та напрямків їі розвитку. Сьогодні найактуальнішим питанням постає модернізація освіти, яка визначається науковцями не лише як перебудова деяких істотних складових освітнього процесу, а як специфічна форма управління розвитком освіти, яка дозволяє системно змінювати структуру, зміст і організацію освітнього процесу в цілому.

Головною системною ознакою сучасного суспільства $є$ його інформатизація, наслідком якої стає інформатизація всіх підсистем суспільства, у тому числі інституту освіти. В соціальному контексті даний інститут є одним з важливих чинників формування і розвитку як окремих суспільних індивідів, так і суспільства загалом.

У своїх роботах провідні вчені переконливо доводять, що впровадження інформа- ційних технологій суттєво впливає на підвищення ефективності навчального процесу і тільки за умов підвищення інформатизації і комп'ютеризації освіти можлива інтеграція системи освіти України до Европейського та світового освітнього інформаційного простору. Також у сучасних наукових дослідженнях підкреслюється, що розвиток інформаційних технологій відкриває широкі можливості доступу до освіти, завдяки чому суспільство в цілому та освітній процес зокрема починають набувати якісно нових форм. Фактично стає можливим говорити про втрату монополії держави на знання i розвиток освіти й оцінювати інформацію як фактор, що інтегрує соціальні, технологічні, економічні, політичні та культурні механізми [3].

Сьогодні існує багато визначень сутності інформаційного суспільства, в залежності від мети, яку ставить науковець, досліджуючи ту чи іншу складову цього суспільства. Якщо умовно поєднати ці спроби, то можна зазначити, що у соціально-філософських дослідженнях існує щонайменш три підходи. Перший підхід найпростіший: перелічення характеристик, які відрізняють цей тип суспільства від усіх інших, тобто визначення тих нових переваг та «бонусів», що надає нам інформатизація. Другий підхід полягає у визначенні структурно-функціональних змін, коли інформаційне суспільство розглядається як наступна ланка (стадія, формація) в історичному розвитку людства. Тоді виявляються фактори, що спричинили саме перехід до цієї наступної ланки та наслідки на майбутнє. Ці підходи можуть грунтуватися на лінійних або циклічних парадигмах розвитку людства, на концепції стійкого розвитку, або на вченні про ноосферу. Продуктивнішим вважається третій підхід, що поєднує два попередніх у визначенні інформаційного суспільства, як безумовно безальтернативного етапу розвитку людства, при якому всі сфери життєдіяльності людини піддаються інформаційному впливу та змінюють власні істотні характеристики, а інформація стає головним соціально-економічним чинником, домінуючим об'єктом виробництва i споживання. 
Основоположники теорії інформаційного суспільства завжди підкреслюють повідну роль знань та інформації в суспільному розвитку. За висловленням Д. Белла, в новому столітті вирішальне значення для економічного і соціального життя, способів виробництва знання, а також характеру трудової діяльності людини набуває становлення нового соціального устрою, що грунтується на телекомунікації. «Коли знання у своїй систематичній формі втягуються в практичну переробку ресурсів (у вигляді винаходу та організаційного удосконалення), - писав він, - можна сказати, що саме знання, а не праця виступає джерелом вартості» [4].

Як відомо, перші практичні кроки інформатизації і комп'ютеризації освіти України були здійснені у другій половині 50 -х років минулого століття, коли комп'ютерними засобами почали оснащуватись провідні вищі навчальні заклади і коли ці засоби в експериментальному режимі почали застосовуватись у навчально-виховному процесі при навчанні елементів програмування i розв'язуванні обчислювальних задач. Широкомасштабна інформатизація освіти почалась у 70-80 роки минулого століття, коли засоби інформаційних технологій почали активно впроваджуватись, передусім, у систему управління освітою [5].

Сьогодні інформатизація освіти сягнула далеко за межі комп'ютеризації та розуміється не тільки як техніко-технологічне забезпечення навчального процесу, а як зміна освітньої парадигми. Це стосується, перш за все, доступу до освіти та інформації. За визнанням українського дослідника В. Ю. Бикова, при формуванні головних цілей подальшого розвитку освіти, проблема інформатизації має ставитися не просто як інформатизація освіти, а інформатизація і парадигма рівного доступу до якісної освіти, де ключовими словами, вихідними положеннями є рівний доступ до якісної освіти, а тому інформатизація освіти передбачає появу нових інформаційно-орієнтованих педагогічних і освітніх технологій, новітніх засобів навчання, створення й використання в педагогічних системах сучасного комп'ютерно орієнтованого навчального середовища, поступове формування і розви- ток комп'ютерно-технологічної платформи інформаційного освітнього простору, електронних інформаційних освітніх ресурсів i мережних сервісів, що його змістовно наповнюють і процесуально підтримують. [6, c. 14-26].

Розгляд інформатизації як одного із шляхів виходу системи освіти 3 кризи, дозволяє стверджувати про наявність тісного зв'язку освітньої проблематики з проблематикою періоду освоєння інформаційної картини світу, усвідомлення єдності законів функціонування інформації у природі та суспільстві, практичного їхнього застосування, створення індустрії виробництва й обробки інформації. У зв'язку з цим цільовими функціями освіти стають: перехід від трансляції досвіду попередніх поколінь до забезпечення виживання на природному, соціальному та духовному рівнях; перетворення освіти в частку життедіяльності людини, коли зміст безперервної освіти напряму визначає характер людських потреб (не потреби задовольняються в результаті одержання освіти, а освіта визначає потреби); перетворення освіти в засіб селекції людства за соціальною, національною, інтелектуальною та іншими ознаками, а також засіб об'єднання народів на загальних принципах буття. [7, c. 50-53].

За допомогою освіти здійснюється формування особистості, вже не викликає сумніву, що за умов інформатизації процес соціалізації змінюеться докорінно. Освіта стає не тільки чинником соціалізації як становлення соціальної людини, тобто людини пристосованої до життя у суспільстві, залученої до соціуму в якості дієздатного та відповідального суб'єкту, наділеного індивідуальною та суспільною свідомістю. Інформатизація освіти полягає у включенні так-би мовити соціалізованого індивіда (тобто на певному рівні соціалізації) до інформаційного світу, як соціокультурного надбання людства. Освіта як чинник соціалізації особистості виконує, таким чином, функцію становлення не просто соціальної, а соціо-інформаційної людини, яка в якості дієздатного суб'єкта ефективно функціонує у двох світах - соціальному та інформаційному. 3 цього приводу слушно зазначають $\lambda$. Рижак і М. Скринник: «Ін- 
формаційне суспільство - це співіснування двох світів: звичного фізичного та віртуального (швидше фізично-віртуального, бо носієм є відома польова фізична субстанція), створеного людиною, що існує у штучному комп'ютерному середовищі. В доінформаційних суспільствах, окрім фізичного світу, існував лише світ, створений уявою та творчістю людини як фольклор, твори літератури та мистецтва. Цей уявний світ не мав універсального глобального характеру і справляв на фізичний світ лише обмежений опосередкований вплив через морально-виховні або соціально-культурні механізми» [8, c. 168]. Зараз цей віртуальний світ набуває характеристик всезагального, необмеженого ані простором, ані часом, що безумовно відбивається на самої сутності освітнього середовища, яке поєднує в інформаційному суспільстві два названих світи.

В умовах інформатизації освіта перестає бути засобом засвоєння готових загальновизнаних знань. Освіта перетворюється на спосіб обміну інформацією між людьми протягом усієї їх життєдіяльності та передбачає не тільки засвоєння одержаних знань, а й віддачу власних надбань. Активний інформаційний обмін став сутністю процесу інформатизації загалом і в освітній сфері зокрема. Тому фундаментальне завдання освіти в інформаційному суспільстві - підготовка людини до життя в інформаційному соціальному просторі.

Історичний шлях розвитку суспільства України, так само як і досвід інших країн, свідчить, що інформатизація соціальної реальності є по суті одним з найбільш визначальних напрямків розвитку всіх його сфер. Важливість всебічного дослідження проблем цього процесу підсилюється тим, що на сучасному етапі суспільство знаходиться в стадії переходу від індустріального до постіндустріального (інформаційного), що передбачає істотні зміни в соціальній структурі та характері суспільних відносин. Обумовленість цього процесу тим актуальніша, що дані зміни носять не зовнішній чи поверховий, а передусім сутнісний характер.

Сутнісний характер процесу інформатизації в сучасному інформаційному суспільстві проявляється в тому, що він змінюе як динаміку соціальних процесів, так і характер розвитку соціуму Процес інформатизації впливає не тільки на реалії сучасного постіндустріального суспільства, але і на способи його розуміння, інтерпретації, зачіпає різні економічні, соціальні, політичні, культурологічні, філософські аспекти. Інформаційне суспільство розвивається як принципово новий вид товариства, задаючи особливий характер соціальних зв'язків.

Перспективи розвитку інформаційного суспільства, представлені у працях теоретиків постіндустріального суспільства, знаходять підтвердження в реальній соціальній практиці. Необхідно відзначити, що перехід від індустріального до постіндустріального суспільства багато в чому залежить від того, наскільки розвинене суспільство в області комп'ютерних технологій. Однак, незважаючи на різний рівень комп'ютеризації суспільства - розвиток ії економіки в цілому, $\epsilon$ загальною тенденцією і являє собою універсальну модель розвитку сучасного суспільства в цілому. Економіка в постіндустріальному суспільстві характеризується тим, що промисловість за показниками зайнятості і основної частки в національному продукті все більше заміщується сферою послуг, яка орієнтується на виробництво і обробку інформації. В інформаційному суспільстві, де інноваційні процеси мають першорядну значимість, неухильно зростає роль освіти. Поряд зі зміною ролі освіти в постіндустріальному суспільстві розширюється також розуміння сутності самого освітнього процесу. Саме тому в числі стратегічних напрямів розвитку освіти, визначених у «Національній стратегії розвитку освіти в Україні на період до 2021 року», затвердженій 25 червня $20 \mathrm{I} 3$ р., визначено іiі інформатизацію, вдосконалення бібліотечного та інформаційноресурсного забезпечення освіти і науки. В розділі «Інформатизація освіти» особливо наголошується, що «Пріоритетом розвитку освіти є впровадження сучасних інформаційно-комунікаційних технологій, що забезпечують удосконалення навчально-виховного процесу, доступність та ефективність освіти, підготовку молодого покоління до життєдіяльності в інформаційному суспільстві» [9]. 


\section{Дискусіі, обговорення, актуально} АНОТАЦІЯ

у статті досліджено питання інборматизациї освіти, що знаходить свій вияв у пошуку подальших шляхів інформатизачій освітнъої сфери, визначення ролі $і$ місия иъього процесу в реалізачиї сучасних концепиій модернізаизї вітчизняної системи освіти та входження ї̈ у світовий освітній простір в умовах євроінтеграиій та становлення інформаційного суспільства. Розкрито інформатизаиію освіти як багатоаспектний процес, оскільки комплексне вирішення проблеми повинно передбачати використання інформаційних технологій у всіх сферах освітнъого життя - навчальному процесі, методичній роботі викладачів, вирішенні адміністративних та управлінсъких завдань тощо.

Ключові слова: інформатизачія освіти, ІКТ, освітне середовище, глобалізачія, трансформаиія суспільства, конкурентоздатність, ринок праці.

\section{Література}

1. Островський Е. Информационные материалы к Internet-лекциям. Аекция: «Политика русской элиты» http://www. eostrovsky.region56.ru.

2. Бабійчук С. Геоінформаційні системи та дистанційне зондування землі як засоби інформатизації дисциплін природничого циклу в Малій Академії наук України. Педагогічні науки: теорія, історія інноваційні технології. 2018. № 1 (75). С. 3-11.

3. Пінчук Є. А. Модернізація Української системи освіти як теоретико-філософська і практична проблема : автореф. дис... д-ра філос.. наук 09.00.10 / С. А. Пінчук; Ін-т вищої освіти НАПН Укр. К., 2010. 25 с.

4. Белл Д. Социальные рамки информационного общества (Новая технократическая волна на Западе). Под. ред. П. С. Гуревича. М.: Прогресс, 1986. 549 с.

5. Биков В. Ю. Сучасні завдання інформатизації освіти. Інформаційні технологї $i$

\section{SUMMARY}

The article explores the issues of informatization of education, which finds its expression in the search for further ways of informatization of the educational sphere, determining the role and place of this process in the implementation of modern concepts of modernization of the national education system and its entry into the world educational space in the context of European integration and the formation of the information society. The informatization of education is revealed as a multidimensional process, since the complex solution of the problem should involve the use of information technologies in all spheres of educational life - the educational process, methodical work of teachers, solving administrative and managerial problems, etc.

Key words: informatization of education, ICT, educational environment, globalization, transformation of society, competitiveness, labor market.

засоби навчання. 2010. №1(15). URL: http:// www.nbuv.gov.ua/e-iournals/ITZN/em 15/emg. $\underline{\text { html. }}$

6. Биков В.Ю. Інноваційні інструменти та перспективні напрями інформатизації освіти. Інбормачійно-комунікаційні технологій в сучасній освіті: досвід, проблеми, перспективи: 3б. наук. праць третьої Міжнар. наук.практ. конф. 12-14 листоп. 2012p. Винницький держ. пед.. ун-т ім. М. Коцюбинського. Винниця, 2012. С. 14-26.

7. Комарова О. А. Освіта у вимірі інформаційного суспільства. Економічний часопис XXI. Науковий журнал. 2011. № 7-8. С. 5053.

8. Рижак А., Скринник М. Філософські підходи до інтерпретації цивілізації. Національні інтереси. Аьвів, 2004. Ч. 11. С. 164179.

9. Національна стратегія розвитку освіти в Україні на період до 2021 року. URL: http://zakon2.rada.gov.ua/laws/show/344/2013. 